\title{
Variations in Algal Floristic and Major Nutrients in Soils of Hassan District
}

\author{
B. Basavaraja ${ }^{1 *}$, T. Parameswara Naik ${ }^{2}$ and Nagaraj Hullur ${ }^{3}$ \\ ${ }^{1}$ Department of Seed Science and Technology, Agriculture Research Station, \\ Madenur, Hassan, India \\ ${ }^{2}$ Department of Botany and Seed Technology, Sahyadri Science College (Auto.), Shivamogga \\ ${ }^{3}$ Department of Seed Science and Technology, College of Agriculture, Hassan, India \\ *Corresponding author
}

\begin{abstract}
A B S T R A C T
Keywords

Algal floristic, Hassan, Organic matter, Paddy, Major nutrients

Article Info

Accepted:

17 April 2019

Available Online:

10 May 2019

An investigation was carried out to know the variations in algal floristic and major nutrients of Hassan district soils. During the study periodic trips were made for soil samples. The soil samples were collected from all the eight taluks of Hassan district viz., Alur, Arkalgud, Arsikere, Belur, Channarayapatna, Hassan, Holenarasipura and Sakaleshpura. Collected soil samples were subjected for estimation of algal floristic composition and physic-chemical properties. The results revealed that significantly more algal floristic composition observed in Holenarasipura and Sakaleshpuraas compare to other taluks followed by Arakalgudu, Channarayapatna and Alur and least was observed in Arasikere. And with respect to physic chemical properties of soil maximum soil fertility parameters viz., Organic matter content, Nitrogen, phosphorous, potassium and other micronutrients were observed in Sakaleshpura and Holenarasipura followed by Arakalgudu, Channarayapatna and least were observed in Arasikere.
\end{abstract}

\section{Introduction}

During soil and ecosystem development, nutrient levels change as a result of weathering. Essential elements for plant growth such as calcium, magnesium, potassium and phosphorus usually have their concentrations reduced, soil $\mathrm{pH}$ and clay activity tend to decrease and mineralogical composition changes (Smeck, 1973; Walker and Syers, 1976; Uehara and Gillman, 1981; Allen and Fanning, 1988). During this process, morphological characteristics of soils are also altered in response to the weathering forces of their environment. Blue-green algae (BGA) are photosynthetic prokaryotic microorganisms some of which are capable of nitrogen fixation. Such trophic independence with regard to nitrogen and carbon, together with a great adaptability to variations of environmental factors enables BGA to be ubiquitous (Fogg et al., 1973). The paddy field ecosystem provides an environment favorable for the growth of BGA with respect to their requirements for light, water, high temperature and nutrient availability. This 
may account for the higher abundance of BGA in paddy soils compared to other cultivated soils. The agricultural importance of $\mathrm{BGA}$ in rice cultivation is directly related with the ability of certain forms to fix nitrogen. Contrary to heterotrophic $\mathrm{N}_{2}$ fixing bacteria, BGA represent a self supporting system capable of both photosynthesis and $\mathrm{N}_{2}$ fixation, the energy bill for both process being "paid by the sun".

\section{Materials and Methods}

The soils of a total of 120 samples were collected for this study across the taluks of Hassan district. These included Alur, Arkalgud, Arsikere, Belur, Channarayapatna, Hassan, Holenarasipura and Sakaleshpura. Soil sampling for all sites was carried out according to a standard protocol.

Soil samples were analysed for algal floristic composition and various physic-chemical properties of soil samples using standard procedures. The estimation of algal floristic composition a drop of the sediments samples were taken on a clean side and all known size of cover slip was put over it and observed under microscope and then the organisms appeared, were counted and tabulated as per the method of Rao (1938).

The $\mathrm{pH}$ of the soil samples was determined following Jackson (1973). The oven dried soil sample weighing $12.5 \mathrm{~g}$ was suspended in 25 $\mathrm{ml}$ of distilled water and stirred continuously. The $\mathrm{pH}$ was measured using calibrated $\mathrm{pH}$ meter. It was determined in soil water suspension using digital conductivity meter as described by Jackson, 1973. The Organic carbon estimated by using the Walkley-Black (1934) Rapid Titration method i.e. wet combustion method. The nitrogen was determined by Macro- kjeldhal method. The phosphorous was estimated as per the stannous Chloride method. The potassium was analyzed by Flame photometer method The experimental data were statistically analyzed as per the methods outlined by Sundararaj et al., (1972) adopting "Fisher's Analysis of Variance Techniques". Critical difference (CD) values were computed at 5 per cent level wherever ' $F$ ' test was significant.

\section{Results and Discussion}

The results revealed that significantly more algal floristic composition observed in Holenarasipura and Sakaleshpuraas compare to other taluks followed by Arakalgudu, Channarayapatna and Alur and least was observed in Arasikere. This is mainly due algal growth is associated with paddy growing area and the regions rich in algal microflora are major paddy growing regions and data is presented in Table 1 and Figure 1, 2,3 and 4.

The soil reaction in Alur taluk ranges from 4.80 to 6.10 with mean of 5.37 and which is moderately acidic in nature. The electrical conductivity of soil ranges from 0.06 to 0.57 $\mathrm{dS} / \mathrm{m}$ with mean of 0.23 and considered as normal in range. The lower $\mathrm{pH}$ and soluble salts attributed to high rainfall area which resulted in leaching of salts as well as basic cations resulted soil to become more acidic. The organic carbon content of soil ranges from 0.57 to 1.28 percent with mean of 0.92 percent which considered as high in range which is attributed to addition of more organic matter to the soil under forest vegetation. The mean available Nitrogen (278 $\mathrm{kg} / \mathrm{ha})$. Phosphorus (51 kg/ha) and potassium content (285 kg/ha) of soil is medium, medium and high in range respectively due to accumulation of clay and organic matter in soil under low land conditions.

Soil reaction in Arkalagudu taluk ranges from 4.36 to 7.83 with mean of 6.18 which is 
highly acidic in nature to slightly acidic condition. The soluble salts content is normal in range $(0.08-0.51 \mathrm{dS} / \mathrm{m})$. The organic carbon content of soil ranges from medium to high in range and with mean of 0.88 percent. The available nitrogen content of soil ranges from high to low in range however the mean value is medium in range. The Phosphorus content of soil ranges from 12 to $95 \mathrm{~kg} / \mathrm{ha}$ with mean of $53 \mathrm{~kg} / \mathrm{ha}$ which is considered as medium in range. The available potassium content of soil ranges from 97 to $598 \mathrm{~kg} / \mathrm{ha}$ (Low to high in range) and the mean value of potassium is $240 \mathrm{~kg} / \mathrm{ha}$ which belongs to medium in range.

The soil properties of Arsikere taluk differ from the Arkalagudu and Alur as Arsikere is coming under Central Dry zone which receives low rainfall unlike that of Arkalagudu and Alur. The soil reaction of Arsikere ranges from 6.01 to 8.96 with a mean of 7.28 which is more towards alkaline in nature. The soluble salts content of soil ranges from 0.08 to $0.23 \mathrm{dS} / \mathrm{m}$ which is normal in range. The soil organic carbon content recorded as low compared to Alur and Arkalagudu and ranges from 0.20 to 0.94 with a mean of 0.55 percent. As regard to available nitrogen status of soil, the available nitrogen content ranges from 187 to 343 and with mean of $250 \mathrm{~kg} / \mathrm{ha}$ which is medium in category. The Available phosphorus and potassium also followed in similar trend and recorded as $25-76 \mathrm{~kg} / \mathrm{ha}$ and 108 to $576 \mathrm{~kg} / \mathrm{ha}$ with a mean of 46 and $327 \mathrm{~kg} / \mathrm{ha}$ respectively.

Soils of Channarayapattana belong to southern dry zone in which coconut based farming system is the major farming system existing in the zone. The major soil textural classes are sandy loam and silty clay loam and in lowlands we can find sandy clay loam soils. The soil reaction $(\mathrm{pH})$ is neutral to alkaline in range (5.57 - 8.10) with mean value of 7.22 and rarely we can find the acidic in small patch of land. The soluble salts content ranges from 0.05 to $0.31 \mathrm{dS} / \mathrm{m}$ with mean of $0.16 \mathrm{dS} / \mathrm{m}$. which considered as normal range. The organic carbon content of soil general low and ranges from 0.18 to 1.08 percent with mean of 00.55 percent due to decline in addition of organic matter to soil through Farm yard manure and non adoption of green manuring in farming community. The available nitrogen content of soil low in range (191-313 kg/ha) with a mean of 243 $\mathrm{kg} / \mathrm{ha}$ which belongs to low category whereas available phosphorus (26-157 kg/ha) and potassium (117to $678 \mathrm{~kg} / \mathrm{ha}$ ) content of soil recorded high with a mean of 88 and 314 $\mathrm{kg} / \mathrm{ha}$ respectively.

Holenarasipura taluk is coming under southern transition zone and major soil types are sandy clay loam, red sandy soil and clay loams. Soil reaction ranges from 4.83 to 7.68 with mean of 5.91 which is almost acidic to neutral in reaction. The soluble salts content of soil ranges from 0.14 to $0.63 \mathrm{dS} / \mathrm{m}$ with a mean of $0.28 \mathrm{dS} / \mathrm{m}$. The organic carbon content of soil ranges from 0.17 to 1.46 percent with a mean of 0.80 percent. The available nitrogen content of soil ranges from low $(194 \mathrm{~kg} / \mathrm{ha})$ to high in range $(464 \mathrm{~kg} / \mathrm{ha})$ with a mean of $279 \mathrm{~kg} / \mathrm{ha}$. The available Phosphorus and Potassium content medium in range with mean of $72 \mathrm{~kg} / \mathrm{ha}$ and $250 \mathrm{~kg} / \mathrm{ha}$ respectively.

Soil reaction in Sakaleshpura taluk ranges from 4.70 to 6.68 with mean of 5.64 which is moderately acidic in nature. The soluble salts content of soil measured in terms of Electrical conductivity ranges from 0.04 to 0.86 with mean of $0.32 \mathrm{dS} / \mathrm{m}$ which considered as normal in range. The organic carbon content of soil ranges from 0.75 to 2.62 percent with a mean of 1.61 percent which is high in range. The available nitrogen content of soil 233 to $555 \mathrm{~kg} / \mathrm{ha}$ with a mean of $409 \mathrm{~kg} / \mathrm{ha}$ which is medium in range. The available $\mathrm{P}$ content of soil ranges from 10.28 to $22.30 \mathrm{~kg} / \mathrm{ha}$ with a 
mean of $16 \mathrm{~kg} / \mathrm{ha}$ which is medium in range. The available potassium content of soil ranges from 45 to $368 \mathrm{~kg} / \mathrm{ha}$ with a mean of 226 $\mathrm{kg} / \mathrm{ha}$ which is of medium in range.

The soil reaction $(\mathrm{pH})$ in Belur taluk ranges from 4.7 to 8.20 with a mean of 6.58 , which is neutral in range. The electrical conductivity o soil ranges from 0.08 to $0.84 \mathrm{dS} / \mathrm{m}$ with a mean of $0.27 \mathrm{dS} / \mathrm{m}$ which is normal in range. The organic carbon content of soil ranges from 0.48 to 1.31 percent with a mean of 0.85 percent which is higher in range. The available nitrogen content of soil ranges from 196 to $299 \mathrm{~kg} / \mathrm{ha}$ with a mean of $243 \mathrm{~kg} / \mathrm{ha}$ which in low in range. The available Phosphorus content of soil ranges from 20 to $86 \mathrm{~kg} / \mathrm{ha}$ with mean of $52 \mathrm{~kg} / \mathrm{ha}$ which is medium in range. The potassium content of soil ranges from 76 to $607 \mathrm{~kg} / \mathrm{ha}$ with mean of $250 \mathrm{~kg}$ per hectare which is high in range.

Table.1 Variation in major nutrients in soils of different taluks of Hassan district

\begin{tabular}{|c|c|c|c|c|c|c|}
\hline $\begin{array}{c}\text { Taluks of Hassan } \\
\text { district }\end{array}$ & $\mathbf{p H}$ & $\begin{array}{c}\text { Electrical } \\
\text { conductivity } \\
\left(\mathbf{d S m}^{-1} \mathbf{)}\right.\end{array}$ & $\begin{array}{c}\text { Organic } \\
\text { carbon } \\
(\mathbf{\%})\end{array}$ & $\begin{array}{c}\text { Nitrogen } \\
(\mathbf{k g} / \mathbf{h a})\end{array}$ & $\begin{array}{c}\text { Phosphorous } \\
(\mathbf{k g} / \mathbf{h a})\end{array}$ & $\begin{array}{c}\text { potassium } \\
\mathbf{( k g / h a})\end{array}$ \\
\hline Alur & 5.37 & 0.231 & 0.23 & 277.9 & 50.9 & 284.5 \\
\hline Arakalagudu & 6.18 & 0.253 & 0.25 & 399.3 & 52.7 & 239.6 \\
\hline Arasikere & 7.28 & 0.140 & 0.14 & 250.1 & 46.2 & 327.0 \\
\hline Belur & 6.58 & 0.266 & 0.27 & 243.5 & 52.0 & 250.2 \\
\hline Channarayapatna & 7.22 & 0.160 & 0.16 & 243.3 & 88.1 & 313.7 \\
\hline Hassan & 6.39 & 0.209 & 0.21 & 318.3 & 53.5 & 271.7 \\
\hline Holenarasipura & 5.91 & 0.278 & 0.28 & 279.3 & 71.7 & 250.4 \\
\hline Sakaleshpur & 5.65 & 0.317 & 0.32 & 409.3 & 16.3 & 225.5 \\
\hline
\end{tabular}

Fig.1 Major nutrient variation different taluks of Hassan district

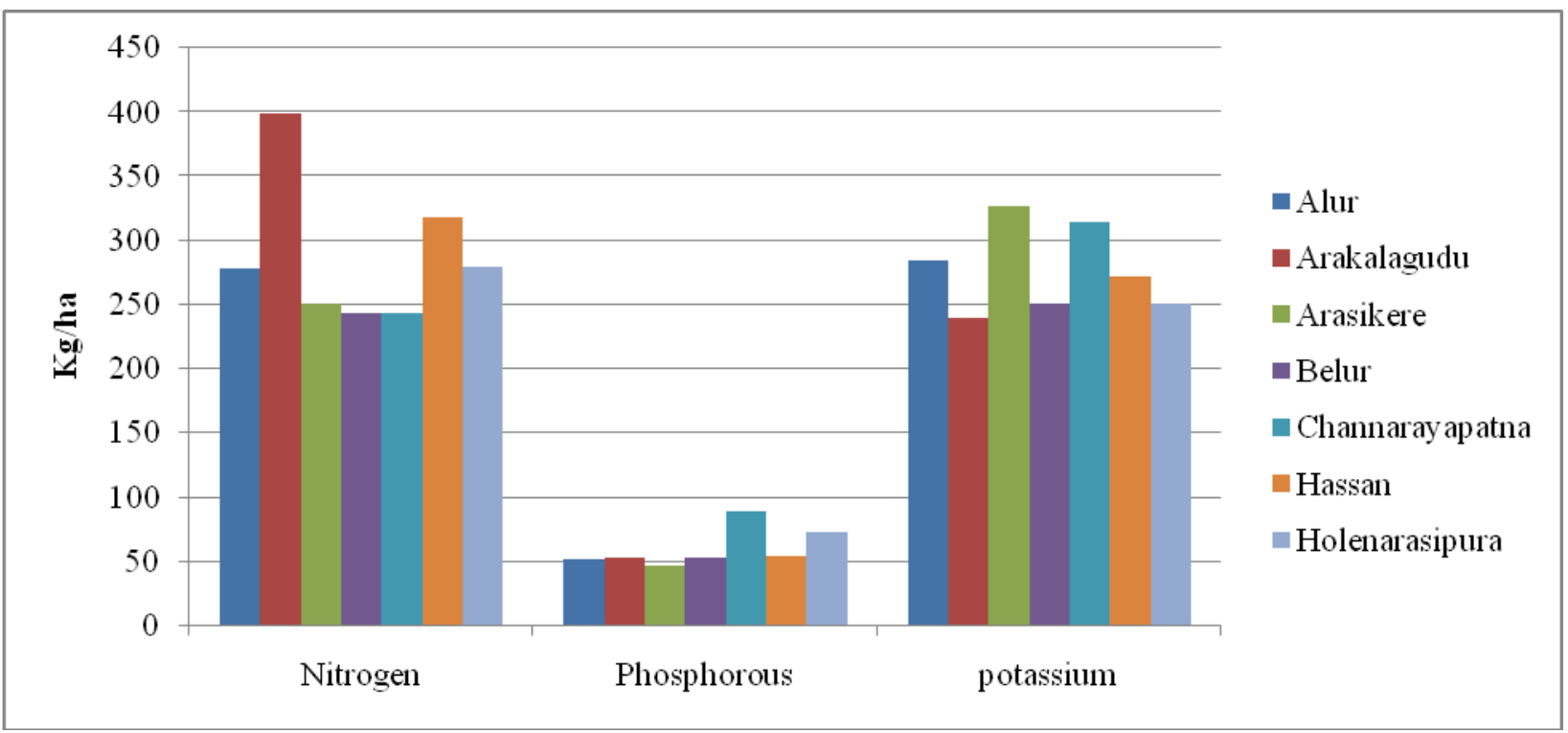


Fig.2 Soil reaction variation different taluks of Hassan district

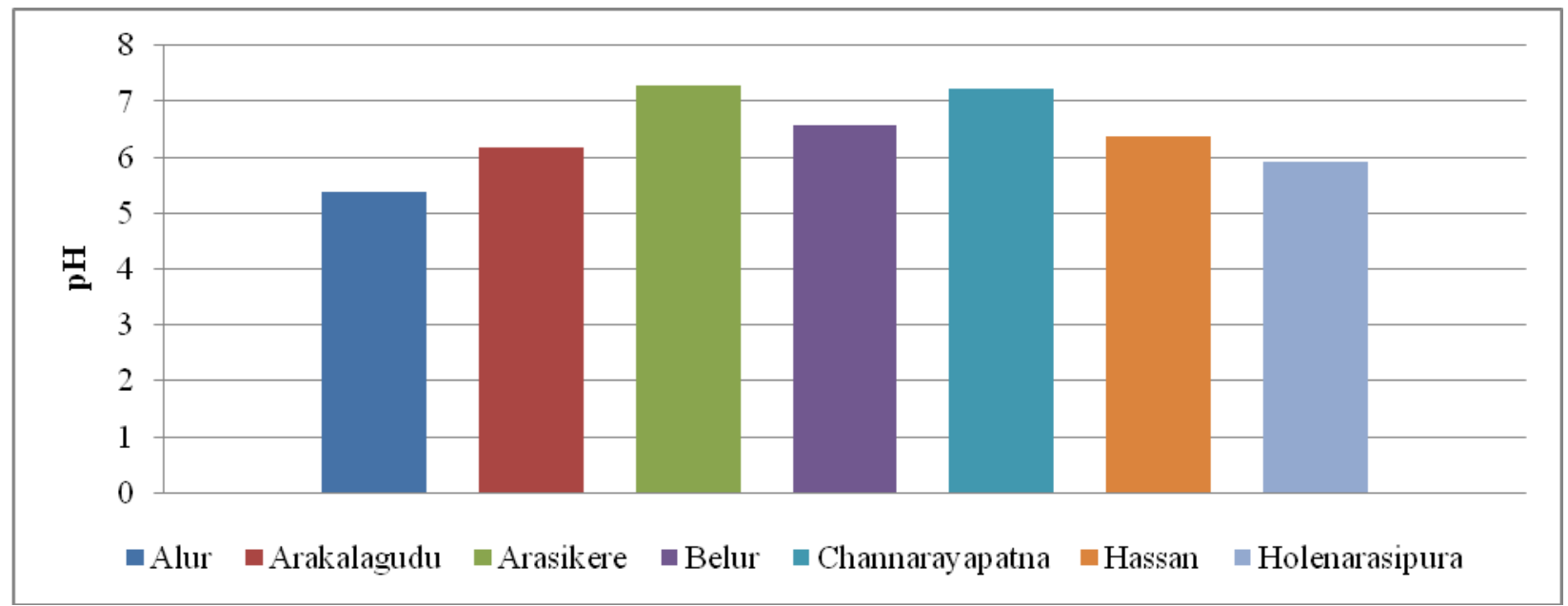

Fig.3 Electrical conductivity $\left(\mathrm{dSm}^{-1}\right)$ variation different taluks of Hassan district

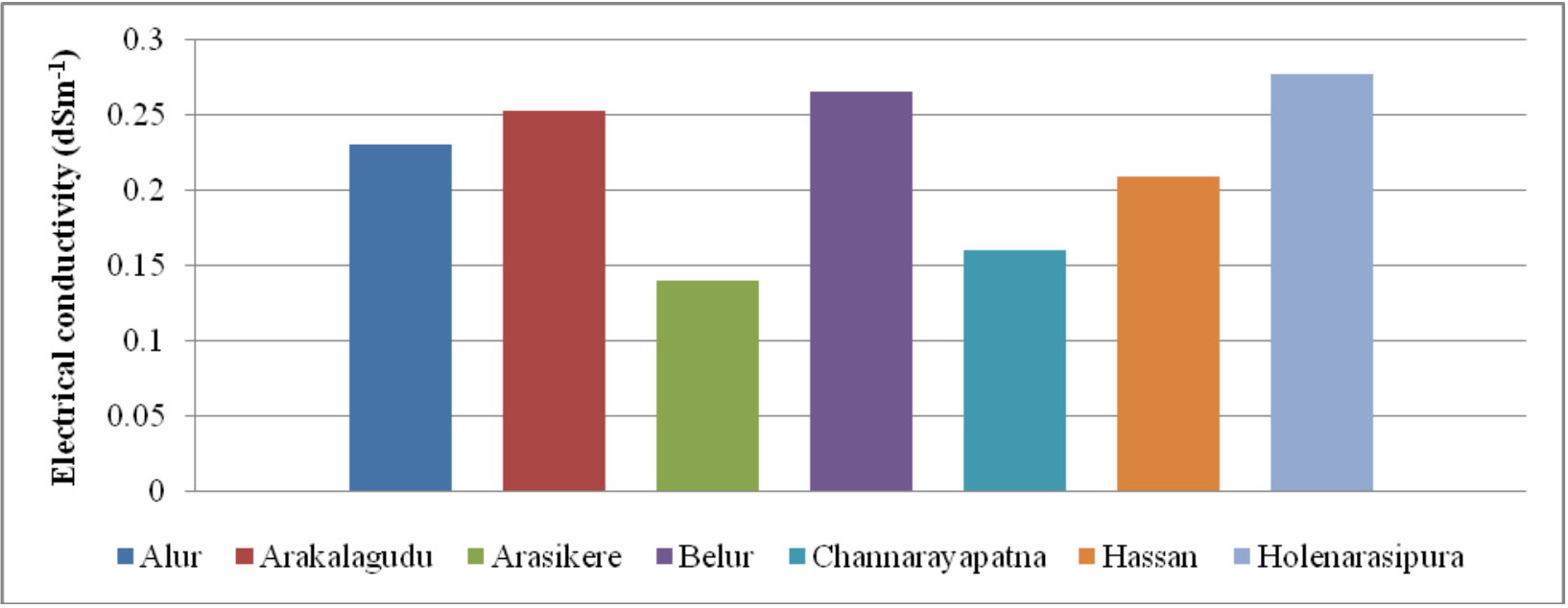

Fig.4 Organic carbon variation different taluks of Hassan district

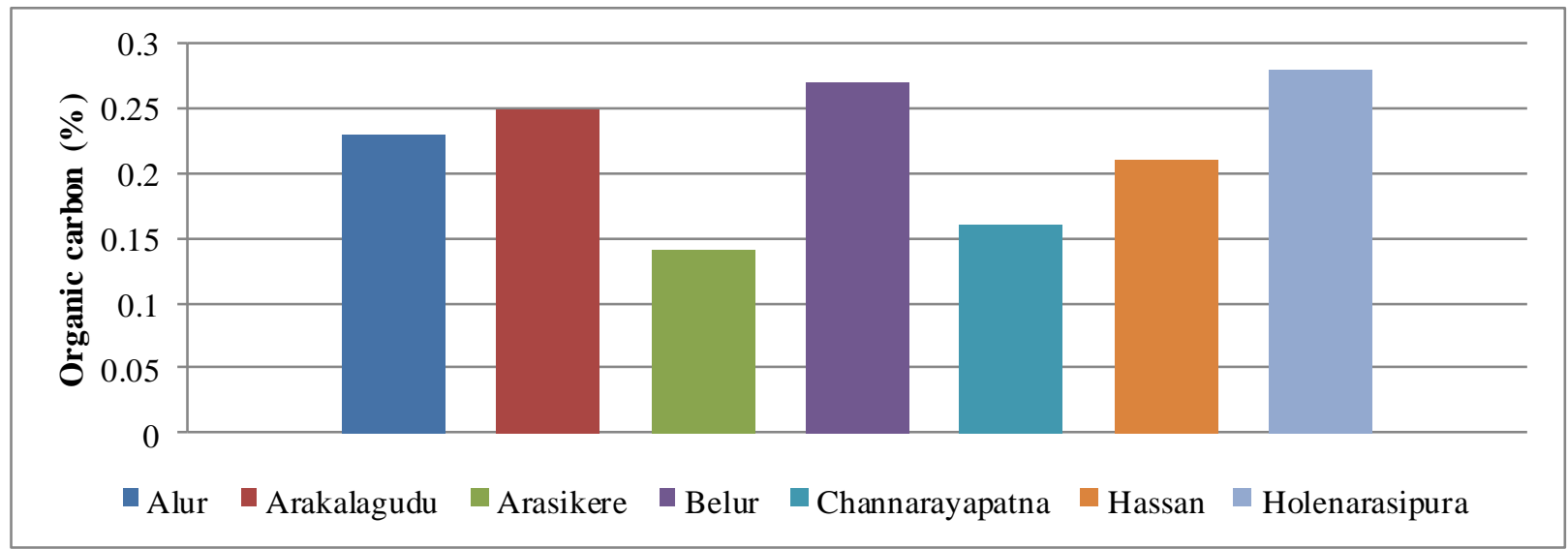


The soil reaction $(\mathrm{pH})$ in Hassan taluk ranges from 5.15 to 7.59 with a mean of 6.39 which is neutral in reaction. The soluble salts content ranges from 0.05 to $0.59 \mathrm{dS} / \mathrm{m}$ and with mean of $0.21 \mathrm{dS} / \mathrm{m}$ which is of normal in range. The organic carbon content of soil ranges from 0.21 to 2.4 percent and with a mean of 0.62 percent which is medium in range. The available nitrogen content of soil ranges from 193 to $511 \mathrm{~kg} / \mathrm{ha}$ with a mean of $318 \mathrm{~kg} / \mathrm{ha}$ which is medium in range. The available phosphorus content soil ranges from 13 to $132 \mathrm{~kg} / \mathrm{ha}$ with a mean of $54 \mathrm{~kg} / \mathrm{ha}$ which is medium in range. The available potassium content of soil recorded higher with range from 98 to $613 \mathrm{~kg} / \mathrm{ha}$ with a mean of $272 \mathrm{~kg} / \mathrm{ha}$.

\section{References}

Allen, B. L. and Fanning, D. S., 1988. Composition and soil genesis, in: Pedogenesis and Soil Taxonomy: Concepts and Interactions, edited by: Wilding, L. P., Smeck, N. E., and Hall, G. F., Elsevier, 141-192.

Fogg, G. E., 1973, The blue green algae. Academic Press, London \& New York.
Jackson, M.L. 1973, Soil Chemical Analysis, Prentice Hall of India Pvt. Ltd., New Delhi, p. 38-56.

Rao, C. B. 1938, The Myxophyceae of the Orissa Province, India-I. Proc. Ind. Acad. Sci., 8: 157-170.

Smeck, N. E. 1973, Phosphorus: An indicator of pedogenetic weathering processes, Soil Sci., 115, 199-206.

Sundararaj, N., Nagaraju, S., Venkataraman, M. N. and Jaganath, M. K. 1972, Design and analysis of field experiments, University of Agricultural Sciences, Bangalore, pp. 165.

Uehara, G. and Gilman, G. 1981. The Mineralogy, Chemistry, and Physics of Tropical Soils with Variable Charge Clays, Westview Press, Boulder, Colorado.

Walker, T. W. and Syers, J. K., 1976. The fate of phosphorus during pedogenesis, Geoderma, 15, 1-19.

Walkley, A. and I. A. Black. 1934. An examination of Degtjareff method for determining soil organic matter and a proposed modification of the chromic acid titration method. Soil Sci. 37: 2937.

\section{How to cite this article:}

Basavaraja, B., T. Parameswara Naik and Nagaraj Hullur. 2019. Variations in Algal Floristic and Major Nutrients in Soils of Hassan District. Int.J.Curr.Microbiol.App.Sci. 8(05): 21102115. doi: https://doi.org/10.20546/ijcmas.2019.805.246 